\title{
CREATINE METABOLISM IN ARTHRITIS
}

\author{
BY \\ J. EUAN DAWSON and HAROLD B. SALT \\ Highfield Hospital, Droitwich, and the Biochemical Laboratory, Royal Infirmary, Worcester
}

(RECEIVED FOR PUBLICATION NOVEMBER 28, 1951)

The results published by Granirer (1949) of his investigation of creatinuria in patients with rheumatoid arthritis and osteo-arthritis appeared especially interesting, as few such studies had previously been recorded.

The extensive work of Wang (1939) on creatine metabolism included a study of only three arthritic patients. All of these were regarded as having significant creatinuria of varying degree, but this was attributed by Wang to the accompanying muscular atrophy. Pemberton and Buckman (1920) had earlier studied forty cases of arthritis in men, with the conclusion that about one-half of these showed an abnormally high value for blood "creatine", but that only three of the cases showed creatinuria. In the control series of nine normal men, no creatinuria was found.

Granirer's results were obtained from adult male and female subjects and yielded the following mean values for the 24-hr urinary creatine excretion:

$675 \mathrm{mg}$. for ten osteo-arthritics

$185 \mathrm{mg}$. for ten elderly healthy controls

$176 \mathrm{mg}$. for ten patients with rheumatoid arthritis

$161 \mathrm{mg}$. for ten young healthy controls.

These findings, together with a consideration of normal levels of creatinuria previously postulated by certain other workers, led Granirer to conclude that creatinuria is a normal process in the adult male and female; that patients with active rheumatoid arthritis have also a normal creatinuria; and that in patients with osteo-arthritis there exists the possibility of an abnormal excretion of creatine.

It is well known that creatine is an integral factor in the activity of muscle and in the cycle of carbohydrate metabolism, although the amount of creatine excreted in the urine depends rather on a process of disposal of creatine present in excess of that required for metabolic needs. The nature and purpose of the process of disposal of the excess creatine are still obscure (Peters and Van Slyke, 1946), though it has been noted by various investigators (quoted by Boland, 1950) that a marked increase in creatinuria was found during the early phase of cortisone and ACTH administration, which increase may or may not continue during the period of treatment.

Using an improved method (Peters, 1942) for the determination of creatine 
in blood plasma and in urine, various workers (see Peters and Van Slyke, 1946) have shown that the concentration of creatine in blood plasma is normally low, being usually below about $0.6 \mathrm{mg}$. per $100 \mathrm{ml}$. plasma in adult males, though frequently somewhat higher in adult females. The normal low levels do not give rise to creatinuria, the appearance of which is dependent upon plasma concentrations in excess of the critical value above mentioned. Hence, it is to be expected that the urine of normal adult males and of the majority of normal adult females will contain no creatine.

This has been confirmed by Maw (1947), who demonstrated the absence of creatinuria in a group of normal young men and in about half of a group of normal young women. When present in the females, the creatine excretion was generally about $50 \mathrm{mg}$. per day, though occasional values up to $150 \mathrm{mg}$. per day were noted.

A recent investigation of the creatine excretion of male patients with fibrositis by Sylvest and Hvid-Hansen (1950) has also yielded supporting evidence. Out of 38 patients, they found that thirty had no creatinuria and that two healthy control men likewise showed no excretion of creatine.

The finding by Granirer (1949) of substantial creatinuria in twenty healthy control subjects as well as in twenty patients with arthritis therefore requires explanation. It seems probable that the results depended on the use for the determination of urinary creatine of the analytical method of Folin (1914), a method based on the classical reaction of Jaffe, which is well known to lack specificity. In this connection, it may be noted that Peters and Van Slyke (1946) ascribed the finding by certain earlier workers of high levels of creatine excretion in normal men to analytical errors. Nevertheless, the markedly greater degree of creatinuria shown by all of the ten patients with osteo-arthritis in Granirer's series still appears to represent an abnormality characteristic of this condition.

We have therefore investigated the incidence and degree of creatinuria in groups of male and female patients with rheumatoid arthritis and osteo-arthritis, and have also determined the plasma creatine levels coincidentally, in an attempt to define more clearly the possibility of abnormal creatine metabolism in arthritis.

\section{Patients Studied}

The patients in our series were selected from those coming to Highfield Hospital for the customary course of Spa treatment. The specimens were taken before this treatment was begun, although all the patients had had some form of physiotherapy at some time previously. They were all ambulant and receiving the usual hospital diet which was regarded as having a negligible influence on creatine metabolism.

Only those patients who could be classified in the broad groups of rheumatoid arthritis and osteo- (or degenerative) arthritis, and who also had minimal soft tissue involvement, were selected for study.

In the series of 68 patients ( 40 women and $28 \mathrm{men}$ ), 33 suffered from rheumatoid arthritis and 35 from osteo-arthritis. Their ages varied from 21 to 61 years, but only seven were under $\mathbf{4 0}$ years. The duration of disease from the onset of symptoms varied in the rheumatoid group from 6 months to 17 years and in the osteo-arthritic group from one to 22 years. None had any neurological involvement, nor did any suffer from thyrotoxicosis, myxoedema, diabetes, or pituitary disturbance. 


\section{Analytical Methods}

Each subject collected the 12-hr urine from 8 p.m. to 8 a.m. The relatively concentrated night-urine specimens were chosen in order to increase analytical sensitivity and to minimize any possible effect of exercise on the excretion of creatine. Although Maw (1947) has shown that creatinuria is not related to any phase of the menstrual cycle, the collection of specimens coinciding with the menstrual period was avoided. The absence of proteinuria was noted in every case. The urinary volume was measured, the creatine concentration recorded in $\mathrm{mg}$. per $100 \mathrm{ml}$., and the content recorded in $\mathrm{mg}$. per 12-hr night urine. Each plasma sample was obtained from oxalated blood, collected at about 10 a.m. after the period of urine collection, and the creatine concentration was recorded in $\mathrm{mg}$. per $100 \mathrm{ml}$. plasma.

The colorimetric reaction of Jaffe in the refined (photelometric) form described by Peters (1942) was used for the determination of creatine in both plasma and urine. This method was claimed by Peters to yield reliable values, and his claim has been substantiated by Allinson (1945) using a specific enzymatic method. It should be noted that Peters's procedure is not applicable to the analysis of whole blood, as erythrocytes contain chromogenic material other than creatine.

\section{Results and Conclusions}

Table I summarizes the analytical results derived from the plasma and urine samples of forty female and 28 male patients respectively. Regarding the results for plasma creatine, it is noteworthy that for female patients, only one value in each of the disease groups exceeded the upper limit of normality $(0.9 \mathrm{mg}$. per $100 \mathrm{ml}$. plasma); whereas for male patients, four values out of fourteen in each of the disease groups exceeded the upper limit of normality $(0.6 \mathrm{mg}$. per $100 \mathrm{ml}$. plasma).

TABLE I

ANALYTICAL DATA FOR 40 FEMALE AND 28 MALE PATIENTS

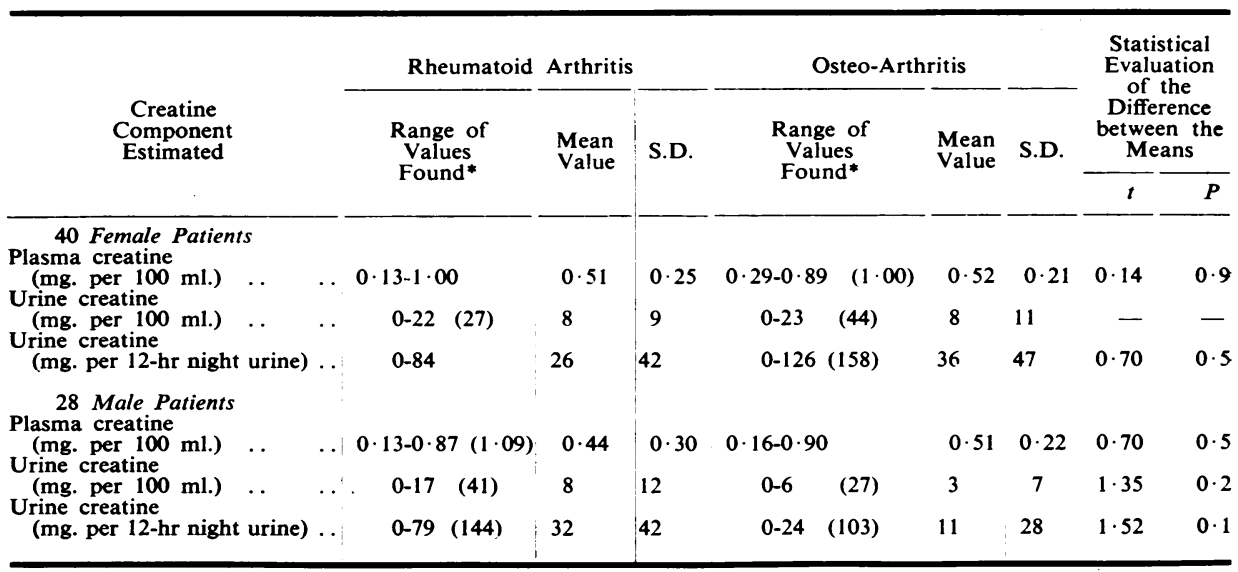

* A single value, where it exceeded the mean +2 S.D., is set out in brackets after the general range of values.

Calculated mean values with standard deviations are shown for each series of analyses in the groups of rheumatoid arthritic and osteo-arthritic patients, together with the values for $t$ and $P$ (Fisher, 1941) which furnish statistical evidence of the significance of the differences between the means. It is evident from the values 
for $P$, all of which exceed $0 \cdot 05$, that none of the pairs of mean values differ to a clearly significant extent. Hence, it is concluded that neither plasma creatine values nor levels of creatinuria are characteristically different in groups of patients who have the types of arthritis here studied.

If it is to be sought further, the possibility of finding a difference lies with greatest probability in the degrees of creatinuria shown by the groups of male patients (where values for $P$ are least).

Many of the patients, both male and female, showed no creatinuria, and Table II presents a numerical distribution of cases based on the presence or absence of this finding, together with the ranges of principal values for creatinuria where this condition was found. Inspection of these ranges of values does indeed suggest that amongst male patients there exists a significant tendency for levels of creatinuria in rheumatoid arthritis (30 to $79 \mathrm{mg}$. per $12 \mathrm{hrs}$ ) to exceed those found in osteoarthritis (11 to $24 \mathrm{mg}$. per $12 \mathrm{hrs}$ ). The numbers of male patients with creatinuria are too small for statistical enquiry to be helpful, but it is noteworthy as supporting evidence that the incidence of creatinuria in male arthritics was higher amongst the rheumatoid group (seven out of fourteen), than amongst the osteo-arthritic group (four out of fourteen).

TABLE II

NUMERICAL DISTRIBUTION OF 68 PATIENTS

WITH VALUES FOR CREATINURIA

\begin{tabular}{|c|c|c|c|c|c|c|}
\hline \multirow{2}{*}{ Creatinuria } & \multirow{2}{*}{ Sex } & \multicolumn{4}{|c|}{ Numbers of Patients and Ranges of Principal Values* } & \multirow{2}{*}{ Total } \\
\hline & & & Rheumatoid Arthritis & & Osteo-Arthritis & \\
\hline \multirow{2}{*}{ Absent } & F & 8 & & 9 & & 17 \\
\hline & $\mathbf{M}$ & 7 & & 10 & & 17 \\
\hline \multirow{2}{*}{ Present } & $\mathbf{F}$ & & $\begin{array}{l}\text { 6-22 mg. per } 100 \mathrm{ml} \text {. } \\
18-84 \mathrm{mg} \text {. per } 12 \mathrm{hrs}\end{array}$ & 12 & $\begin{array}{l}2-23 \mathrm{mg} \text {. per } 100 \mathrm{ml} \text {. } \\
12-126 \mathrm{mg} \text {. per } 12 \mathrm{hrs}\end{array}$ & 23 \\
\hline & $\mathbf{M}$ & 7 & $\begin{array}{l}3-17 \mathrm{mg} \text {. per } 100 \mathrm{ml} \text {. } \\
30-79 \mathrm{mg} \text {. per } 12 \mathrm{hrs}\end{array}$ & 4 & $\begin{array}{l}\text { 2- } 6 \mathrm{mg} \text {. per } 100 \mathrm{ml} \text {. } \\
11-24 \mathrm{mg} \text {. per } 12 \mathrm{hrs}\end{array}$ & 11 \\
\hline Total & & & 33 & & 35 & 68 \\
\hline
\end{tabular}

* Values given in Table I, which exceeded the mean +2 S.D., are here omitted.

In order to apply statistical tests to the groups of all those with positive creatinuria, the results for male and female patients were combined (Table III, opposite). The mean values for the rheumatoids and osteo-arthritics do not differ significantly, the values for the statistic $P$ being greatly in excess of 0.05 .

It thus appears that a trend of difference in respect of creatinuria between patients with the two types of arthritis was demonstrable only in males. This finding is logical and to be expected, considering the small tendency for any such demonstrable difference to exist and the greater likelihood of its detection amongst males; for normal male adults excrete no creatine (or, infrequently, very little), 
TABLE III

SUMMARY OF ANALYTICAL DATA FOR 34 PATIENTS

IN WHOM CREATINURIA WAS FOUND

\begin{tabular}{|c|c|c|c|c|c|c|c|c|}
\hline \multirow{3}{*}{$\begin{array}{l}\text { Creatine } \\
\text { Estimation }\end{array}$} & \multicolumn{3}{|c|}{$\begin{array}{l}\text { Rheumatoid Arthritis } \\
\text { (18: } 11 \text { female, } 7 \text { male) }\end{array}$} & \multicolumn{3}{|c|}{$\begin{array}{c}\text { Osteo-Arthritis } \\
\text { (16: } 12 \text { female, } 4 \text { male) }\end{array}$} & \multirow{2}{*}{\multicolumn{2}{|c|}{$\begin{array}{l}\text { Statistical } \\
\text { Evaluation } \\
\text { of the } \\
\text { Difference } \\
\text { between the } \\
\text { Means }\end{array}$}} \\
\hline & \multirow[t]{2}{*}{$\begin{array}{l}\text { Range of } \\
\text { Values* }\end{array}$} & \multirow[t]{2}{*}{$\begin{array}{l}\text { Mean } \\
\text { Value }\end{array}$} & \multirow[t]{2}{*}{ S.D. } & \multirow[t]{2}{*}{$\begin{array}{l}\text { Range of } \\
\text { Values* }\end{array}$} & \multirow[t]{2}{*}{$\begin{array}{l}\text { Mean } \\
\text { Value }\end{array}$} & \multirow[t]{2}{*}{ S.D. } & & \\
\hline & & & & & & & $t$ & $P$ \\
\hline $\begin{array}{l}\text { Urine creatine (mg. } \\
\text { per } 100 \mathrm{ml} .)\end{array}$ & $3-27 \quad(41)$ & 15 & 9 & $2-27$ & 13 & 11 & $0 \cdot 58$ & 0.6 \\
\hline $\begin{array}{l}\text { Urine creatine (mg. } \\
\text { per 12-hr night } \\
\text { urine) }\end{array}$ & $18-84$ (144) & 52 & 30 & $11-126(158)$ & 57 & 45 & $0 \cdot 38$ & 0.7 \\
\hline
\end{tabular}

* A single value, where it exceeded the mean +2 S.D., is set out in brackets after the general range of values.

whereas normal females frequently exhibit degrees of creatinuria large enough to obscure any increment which may arise through the development of arthritis.

The method used for the determination of creatine also yielded values for creatinine concentrations. The plasma values were substantially normal throughout the whole series of patients, so that only the ranges (with mean values in italics) need be quoted (Table IV).

TABLE IV

\begin{tabular}{|c|c|c|}
\hline Disease & Sex & Plasma (mg. $/ 100 \mathrm{ml})$. \\
\hline Rheumatoid Arthritis & $\begin{array}{l}\text { Male } \\
\text { Female }\end{array}$ & $\begin{array}{l}0.6-1.0-1.8 \\
0.5-0.9-1.9\end{array}$ \\
\hline Osteo-Arthritis $\ldots$ & $\begin{array}{l}\text { Male } \\
\text { Female }\end{array}$ & $\begin{array}{l}0.8-1 \cdot 0-1 \cdot 6 \\
0 \cdot 6-0.9-1.3\end{array}$ \\
\hline
\end{tabular}

The output of urinary creatinine was correspondingly normal in every case.

\section{Discussion}

The results now presented indicate that no large or characteristic abnormality of creatine metabolism is likely to be found in chronic arthritis. The suggestion that there is a higher incidence and higher levels of creatinuria amongst males suffering from rheumatoid arthritis, compared with males who have osteo-arthritis, is in direct contrast to the conclusions put forward by Granirer (1949) concerning both male and female patients. Although it is now well established that creatinuria is common in many diseases affecting the general musculature, it seems unlikely that varying degrees of soft-tissue involvement complicating the cases of arthritis could account for the disparity of the opposite conclusions now being considered. Such variation amongst arthritic patients is, however, a probable factor influencing 
the degree and frequency of creatinuria as it may be found amongst male patients with rheumatoid arthritis.

Reference has already been made to recent observations (quoted by Boland, 1950) on the influence of certain hormones on creatinuria in arthritic subjects. In the wider field, extensive studies of creatine metabolism in various endocrine disorders are still being pursued by many investigators, in the hope of clarifying our knowledge of the factors which influence the biochemistry of creatine. When these studies are more complete, the role of creatine in arthritic disorders will become more clearly defined.

\section{Summary}

(1) The views previously put forward by other workers concerning creatine metabolism in normal subjects and in patients with arthritis are briefly considered.

(2) The values for plasma creatine concentrations and the incidence and degree of creatinuria found in a series of forty females and 28 males are recorded. The analytical values have been examined statistically.

(3) No clearly significant differences could be detected between those with rheumatoid arthritis and those with osteo-arthritis, either males or females, in respect of plasma creatine concentrations or levels of creatinuria. Altogether seventeen males and seventeen females showed no creatinuria.

(4) No clearly significant differences in the degree of creatinuria, characteristic of the type of arthritis, could be found in those patients, eleven males and 23 females who were found to excrete creatine.

(5) Amongst the male patients a slightly higher incidence and a slightly greater degree of creatinuria did occur in the rheumatoid group than in the osteo-arthritic group. This trend was not demonstrable amongst the female patients. Possible explanations for these findings are suggested.

Our grateful appreciation is accorded to Miss P. Arnold for her practical assistance throughout this investigation.

Allinson, M. J. C. (1945). J. biol. Chem., 157, 169.

Boland, E. W. (1950). Annals of the Rheumatic Diseases, 9, 1.

Fisher, R. A. (1941). "Statistical Methods for Research Workers". 8th ed., p. 120. Oliver and Boyd, Edinburgh.

Folin, O. (1914). J. biol. Chem., 17, 469.

Granirer, L. W. (1949). Ann. intern. Med., 30, 961.

Maw, G. A. (1947). Biochem. J., 41, 482.

Pemberton, R., and Buckman, T. E. (1920). Arch. intern. Med., 25, 335.

Peters, J. H. (1942). J. biol. Chem., 146, 179.

Peters, J. P., and Van Slyke, D. D. (1946). "Quantitative Clinical Chemistry-Interpretations ", 2nd ed., vol. I, p. 897. Baillière, Tindall and Cox, London.

Sylvest, O., and Hvid-Hansen, N. (1950). Annals of the Rheumatic Diseases, 9, 241.

Wang, E. (1939). Acta med. scand., Suppl., 105.

Métabolisme de la créatine au cours d'arthrite

\section{RÉSUMÉ}

(1) On considère brèvement les opinions des autres auteurs sur le métabolisme de la créatine chez les sujets normaux et arthritiques.

(2) Chez 40 femmes et 25 hommes on détermina le taux de la créatine dans le plasma et on nota sa fréquence et sa concentration dans l'urine. Les chiffres obtenus furent soumis à l'analyse statistique. 
(3) On n'a pas pu déceler de différences nettement significatives entre les arthritiques rhumatisants et les ostéoarthritiques, hommes ou femmes, en ce qui concerne leur créatinémie ou créatinurie. Chez 17 hommes et 17 femmes il n'y eut pas d'excrétion urinaire de créatine.

(4) Chez les malades qui excrétaient de la créatine-11 hommes et 23 femmes-on ne trouva pas de chiffres suffisamment significatives pour caractériser le type d'arthrite.

(5) Les petites différences qu'il y avait concernaient la créatinurie qui, chez les hommes, était plus fréquente et plus accentuée dans les cas d'arthrite que dans ceux d'ostéoarthrite. Chez les femmes on ne vit pas de tendance semblable. On offre des explications de ces faits.

\section{El metabolismo de la creatina en la artritis}

\section{SUMARIO}

(1) Se considera brevemente las opiniones de otros autores sobre el metabolismo de la creatina en sujetos normales y artríticos.

(2) En 40 mujeres y 28 hombres se determinó los valores de la creatina en el plasma y se notó su frecuencia y su concentración en la orina. Los resultados fueron analizados estadísticamente.

(3) No fueron encontradas diferencias netamente significativas entre los casos de artritis reumatoide y los de osteoartritis, en hombres o en mujeres, respecto a creatinemia o creatinuria. No hubo creatinuria en 17 hombres ni en 17 mujeres.

(4) Los enfermos con creatinuria-11 hombres y 23 mujeres-no presentaron valores netamente significativos para poder caracterizar el tipo de artritis.

(5) Las pequeñas diferencias encontradas interesaban la creatinuria de los hombres; ésta era más frecuente y más acentuada en los casos de artritis reumatoide que en los de osteoartritis. En las mujeres no se vió tal tendencia. Se sugiere explicaciones de estos hechos. 